\title{
National Governance System, Corporate Ownership, and Roles of Outside Directors: A Corporate Governance Bundle Perspective
}

\author{
Toru Yoshikawa \\ Lee Kong Chian School of Business \\ Singapore Management University \\ Hongjin Zhu \\ DeGroote School of Business \\ McMaster University, Canada \\ Pengji Wang \\ Faculty of Law Business and Creative Arts \\ James Cook University, Singapore Campus
}

Accepted for publication in Corporate Governance: An International Review. 


\section{National Governance System, Corporate Ownership, and Roles of Outside Directors: A Corporate Governance Bundle Perspective}

Manuscript Type: Conceptual

Research Questions/Issues: Drawing upon insights from research on comparative corporate governance and board of directors, we investigate how outside directors serve the functions of managerial monitoring and resource provision in different systems of corporate governance. Rather than viewing outside directors as functioning independently in the context of organizational environment, we conceptualize them as an element of bundles of related corporate government practices. Specifically, we explore why and how the different combinations of governance practices at national level, such as the legal system, conduct codes, and capital markets, and at firm level, such as various types of controlling shareholders, enable or constrain outside directors to engage in the monitoring and resource provision roles. Building upon such analysis, we develop a new taxonomy of corporate governance systems according to the different configurations of a set of interdependent governance characteristics, including national governance mechanisms, identity of block shareholders, and functions of outside directors.

Research Insights: Recent research on comparative corporate governance suggests that it is critical to examine complementarity and substitution of corporate governance practices at both firm level and national level when we evaluate their effectiveness. This study enriches this growing body of research by highlighting the role of bundles of governance practices in influencing directors' engagement in governance behavior, and consequently advancing our understanding on variation in corporate governance systems across and within countries.

Theoretical/Academic Implications: By explicitly considering how different governance practices at national level and firm level complement and substitute each other, this paper demonstrates that the roles of outside directors depends on the interaction between a bundle of governance mechanisms rather than any individual mechanisms. The paper also goes beyond the traditional governance models based on the national context and highlights that interdependencies of corporate governance practices play an important role in explaining the diversity and variation of corporate governance arrangements across firms in both industrialized economies and emerging markets.

Practitioner/Policy Implications: This paper provides insights to policy makers by suggesting that not all the governance bundles are conducive to managerial monitoring and resource provision by outside directors. To enhance desirable director functions, the government may improve national-level governance institutions, while firms may promote complementary types of block shareholders.

Key words: Outside directors, types of controlling shareholders, national governance systems, corporate governance bundles 
In the presence of many corporate scandals in recent years (e.g., Enron Scandal, WorldCom Fraud), increased debate on and interest in the roles and effectiveness of outside directors has emerged in academia, industry, and regulatory institutions in both developed and emerging economies (e.g., Carter \& Lorsch, 2004; CSRC, 2001). The vast bulk of research on the antecedents of directors' behavior conceptualizes outside directors as an independent governing mechanism whose efficacy is determined by directors' incentives and ability to engage in two primary functions, monitoring the management and providing resources/counseling to the management (Adams \& Ferreira, 2007; Hillman \& Dalziel, 2003; Sundaramurthy \& Lewis, 2003). Agency theorists contend that independence of outside directors brings greater transparency, efficiency, and accountability to managerial monitoring (Fama \& Jensen, 1983). Resource dependence theorists view outside directors as critical resource providers who, use their human and social capital to provide advice and counseling, connections to other organizations, access to external resources, and legitimacy to the firm (Pfeffer \& Salancik, 1978). Theoretically, the presence of outside directors should lead to better firm performance, but the empirical findings about the performance implication of such directors are mixed (e.g., Dalton, Daily, Ellstrand, \& Johnson, 1998; Finkelstein \& D’Aveni, 1994; Peng, 2004; Westphal, 1999).

One explanation for the divergent findings is that those studies focus on outside directors per se without considering their relationships with other governance mechanisms. To the extent that various corporate governance practices coexist within and outside firms, they collectively constitute the context of governance environments that imposes both constraints and enablers on outside directors (Filatotchev, 2008; Rediker \& Seth, 1995; Yoshikawa \& Rasheed, 2009). To better explain the behavior of those directors and their willingness to engage in specific 
governance tasks, it is necessary to take a set of interrelated corporate governance practices into consideration.

Specifically, we go beyond the traditional "actor-centered" approach that focuses on the personal characteristics of outside directors and adopt the original configurational approach to discuss how the interdependencies between multi-level corporate governance mechanisms shape outside directors' behavior in managerial monitoring and resource provision (Aguilera \& Jackson, 2003; Aguilera, Desender, \& Castro, 2011; Ward, Brown, \& Rodriguez, 2009). We argue that outside directors' willingness to engage in the two governance functions depends on the benefits and costs related to the legal and regulatory environment, as well as social structural relationships between corporate elites. Agency theorists suggest that national governance systems based on formal legal systems and informal standards affect the protection of shareholders and information disclosure through enforcement of corporate laws, voluntary compliance with conduct codes, and market for corporate control (La Porta et al. 1998; Shleifer \& Vishny 1997; Weimer \& Pape, 1999). Well-developed national governance systems may promote outside directors to fulfill their obligations by supplying requisite information for decision-making and imposing high costs on them if they fail to accomplish the tasks (Davis, 2002; Hartley, 2009). Meanwhile, the sociological perspective of corporate governance indicates that outside directors' behavior is also influenced by informational and incentive constraints and their interplay with organizational elites, such as large owners (North, 1990; Westphal \& Zajac, 2013). We hence consider how firm ownership structure (Filatotchev \& Nakajima, 2010; Morck, Wolfenzon, \& Yeung, 2005) and national governance system collectively shape outside directors' engagement in monitoring and resource provision. 
By focusing on three types of prevailing owners (i.e., family, state, and dispersed institutional investors) and two types of national governance systems (well-developed vs. underdeveloped), we investigate how governance mechanisms interact with each other in particular legal and socially situated contexts and consequently influence outside directors' behavior. Furthermore, we regard the interrelated governance mechanisms as a governance bundle and develop a taxonomy of corporate governance models based on the different configurations of the governance bundle.

Our discussion on the interaction between outside directors and other governance practices highlights the role of corporate governance bundles in shaping outside directors' governance behavior and consequently helps explain the variation in outside directors' roles across and within countries. Moreover, we enrich the literature on comparative corporate governance by offering a new categorization of corporate governance models that integrates firm-level and national-level governance mechanisms. In so doing, we respond to calls from scholars such as Aguilera, Desender, and Castro (2011) for more fine-grained taxonomies of corporate governance models that go beyond the traditional dichotomous models in which the national context equates with governance systems.

The structure of this paper is as follows. First, we develop the construct of corporate governance bundle by conceptualizing national governance system and ownership structure as two critical components that interact with each other and subsequently affect outside directors' governance behavior. Second, we develop specific propositions about how outside directors' willingness to engage in managerial monitoring and resource provision is contingent on the configurations of corporate governance practices. Finally, we discuss the implications of this 
configurational approach for future research and for multiple effective designs of corporate governance bundles.

\section{MULTI-LEVEL COPORATE GOVERNANCE BUNDLES}

\section{Corporate Governance Bundles}

The concept of a "bundle of governance mechanisms" was initially introduced by Rediker and Seth (1995) and has been attracting increasing scholarly attention. It refers to a combination of corporate governance practices that interact and consequently complement or substitute each other as a bundle of related practices (Aguilera et al., 2011; Rediker \& Seth, 1995; Ward et al., 2009). A number of studies have provided insights on the governance bundles, putting board of directors as part of the intertwined mechanism. One line of research focuses on the complementary and substitutive relationships between firm-level mechanisms, particularly between board of directors and other firm-level mechanisms. For example, Rediker and Seth (1995) find substitution effects between board monitoring, monitoring by outside shareholders, and managerial incentive alignment. Desender and his colleagues (2013) demonstrate that board function of monitoring is contingent on firm ownership and the type of controlling shareholder. Hoskisson, Castleton and Withers (2009) propose that intense monitoring will lead to higher executive compensation in the long run because managers under close monitoring bear higher employment and career risks that need to be offset by higher compensation. Ward and his colleagues (2009) suggest that firm performance determines how external monitoring by institutional investors and internal monitoring by boards function as complements or substitutes. These studies show that board is an important internal governance mechanism whose efficacy depends on its interplay with other mechanisms. However, as most studies are conducted within 
a single national governance system (except Desender et al., 2013), they are silent in how the intertwining mechanisms of firm-level bundles may vary across nations or institutional contexts.

Another line of research investigates the governance bundles composed of multi-level governance mechanisms, wherein board of directors operates in. For example, Weimer and Pape (1999) present two systems, i.e., market-oriented system characterized by dispersed ownership structure with an efficient market for corporate control and network-oriented system in which controlling owners or other oligarchic groups determine managerial decisions via crossshareholdings and interlocking directorships. Franks and Mayer (2001) develop the "insider" and "outsider" paradigms based on corporate ownership and control systems. The insider system, mainly adopted by Continental European countries, features monitoring and control by owners with large stakes in firms and cooperation between majority shareholders and management (Barca \& Becht, 2001). In contrast, the outsider system prevalent in the U.S. and the U.K. is characterized by oversight and control by company outsiders, such as non-executive board members and active market for corporate control, rather than by owners.

Although these models are insightful, they implicitly assume that dispersed ownership structure is associated with well-developed national governance system characterized by strong legal protection of shareholders and efficient capital market, and concentrated ownership often goes hand-in-hand with under-developed national governance system where weak legal protection of shareholders and ineffective capital market are prevalent. However, there are firms with block shareholders in countries that have well-developed governance systems, such as Microsoft, Ford, and Wal-Mart in the U.S., and firms with dispersed ownership in countries with relatively weak governance systems, including China, India, and Continental Europe. Indeed, the 
"within-country differences" in corporate governance mechanisms across firms are much larger than scholars have assumed so far (Jacoby, 2005). Therefore, it is necessary to consider heterogeneity in corporate governance practices within a particular national corporate governance system when explaining the relationship between corporate governance bundles and firm outcomes (García-Castro, Aguilera, \& Ariño, 2013). Moreover, prior studies mainly focus on board structure in different national systems, paying little attention to the interaction between board functions, especially the role of outside directors, and other governance mechanisms.

As an important internal governance mechanism, outside directors are likely to be influenced by other relevant components in a governance bundle when determining their engagement in monitoring and resource provision. Our focus on the interplay between national governance system, corporate ownership structure, and outside directors will allow us to better understand the function of this governance mechanism.

\section{National Governance System}

National governance system is designed and implemented to minimize agency cost ( $\mathrm{La}$ Porta, Lopez-de-Silanes, \& Shleifer, 1999). It consists of formal institutions such as laws and regulations, political and economic rules and procedures, and other explicit constraints on firm behavior, as well as informal institutions including unwritten, yet quite influential, societal norms, conventions, codes of conduct and values (North 1990). These formal and informal institutions engender organizational forms in a country, which in turn determine the distribution of power - how ownership is assigned, managerial decisions are made and monitored, information is audited and released, and profits and benefits allocated and distributed (Cornelius \& Kogut, 2003). 
As an important element of national governance system, legal system, or what North calls "formal constraints" (1990), defines the structure, obligations, and rights of economic actors including those of shareholders, board directors, and managers. The legal system also involves third-party enforcement mechanisms that ensure economic actors obey laws and regulations in economic activities. Prior research suggests that the effectiveness of a national governance system hinges on the development of the legal system. An effective legal system protects shareholders from being expropriated by the firm's management, and protects minority shareholders from being expropriated by large blockholders (La Porta, et al, 1997; 1998; Martynova \& Renneboog, 2010). Hence, the presence of comprehensive laws and regulations together with effective enforcement mechanisms indicates a well-developed national governance system.

The U.S. has a national governance system typically dominated by formal institutions. It developed an extensive body of securities and corporate law (i.e., 'hard law') at both the federal and state levels. The most recent manifestation of the hard law approach in the U.S. was the passage of the Sarbanes- Oxley Act (SOX) in 2002, in which the U.S. Congress mandated stringent governance regulations and increased the costs of noncompliance to all public firms. Through legislative action, SOX required firms to put in place a number of measures intended to reduce conflicts and enhance the role of independent directors.

Facing more stringent corporate laws and governance regulations, the board is under greater pressure to perform its regulatory duty. Shareholders can exercise their voting power on director selections and even sue directors or the majority owners for suspected expropriation (La Porta et al., 2000). The regulatory agency can also punish board members for their negligence. 
Moreover, the effective enforcement mechanisms also dictate the mandatory information disclosure and regulate market intermediaries (Black, 2001; Coffee, 1999; Levine, 1998; Levine \& Zervos, 1996; Pistor et al., 2000), thus alleviating information asymmetry and reducing information cost (Black \& Kraakman, 1996; La Porta et al., 1997; 1998; 1999). In addition, on the basis of clear legal requirements of board duties and information disclosure, capital markets can serve as an effective external governance mechanism (Black, 2001; Coffee, 1999; Levine, 1998; Levine \& Zervos, 1996; Pistor et al., 2000) through allocative and disciplinary measures and takeover mechanisms (Samuel, 1996; Singh, 2003). For example, the stock market and the market for corporate control can improve corporate governance and firm performance by replacing inefficient managers and transferring the firm assets to those who can manage them more efficiently through hostile takeovers, management buy-outs, and leveraged buy-outs (Jensen, 1988; Shleifer \& Vishny, 1986).

The national governance system may also be dominated by informal institutions, for example in the U.K., where voluntary compliance with conduct code dominates the governance activities, and legislative framework does not specify rules on corporate governance mechanism (Moore et al., 2012). Such voluntary compliance is supported by firms' efforts to gain sociopolitical and cognitive legitimacy either through obtaining certification by the third parties (e.g., highly prestigious underwriters, credible venture capital firms) (Moore et al., 2012), or through enhancing reputation via the market intermediaries (e.g., financial analysts and bond rating agencies) (Luo \& Chung, 2013). In the national governance system dominated by informal institutions, the maintenance of reputation and legitimacy is the major driving force for voluntary regulative approach. 
In well-developed national governance systems, the effective enforcement of corporate laws and voluntary compliance of conduct codes may protect shareholders from expropriation by the management and large blockholders. The effective enforcement may also motivate outside directors to fulfill their obligations by providing requisite information and imposing higher litigation, reputation and legitimacy costs on failure in governance tasks. In contrast, in underdeveloped national governance systems where laws, regulations and conduct codes regarding corporate governance are either absent or cannot be enforced effectively (Rajagopalan \& Zhang, 2008), outside directors' incentive to fulfill their obligations are likely to be weak because of information asymmetry, weak legal protection of shareholders, ineffective market for corporate control and consequently, relatively low risk of punishment for failure to perform their governance roles. Typical examples include China, India, Indonesia, Russia, and other emerging economies.

\section{Shareholders as a Corporate Governance Mechanism}

The ownership structure is diverse across countries, with dispersed ownership prevailing in the U.S.- and U.K. -listed firms, and concentrated ownership more prevalent in Continental Europe (La Porta, et al, 1999) and transition and emerging economies (Douma, Rejie \& Rezaul, 2006). Shareholders may act as an internal governance mechanism through their control over stakes in firms and such shareholder control can range from a sole majority owner to numerous small shareholders. Compared with small shareholders, controlling shareholders have both stronger incentives and superior power to discipline and influence management because of their large stakes in the firms and their authority in decision-making, sometimes derived from 
pyramidal ownership structure and possession of multiple key managerial positions (Morck et al., 2005).

Shareholder control is likely to influence other elements of the corporate governance bundle, particularly board behaviors. Desender et al. (2009) show that controlling shareholders influence the priorities of the board to engage in monitoring and resource provision. For example, boards of widely held firms focus more on monitoring. However, they regard controlling shareholders as homogeneous, neglecting the fact that different types of owners differ in their interests, objectives and even resource endowment (Fiss \& Zajac, 2004; Peng, Tan, \& Tong, 2004), and thus may exert different demands on boards and disciplinary effects on managers (Adams, Hermalin, \& Weisbach, 2010; Aguilera \& Jackson, 2003). Desender and his colleagues (2013) differentiate types of owners and demonstrate how their differential incentives and capabilities to monitor management affect the monitoring role of the board, but the resource provision role of the board is left on the sideline in their study.

Our focus is the impact of different types of owners on outside directors' role in managerial monitoring and resource provision. In particular, we consider three typical types of controlling shareholders prevalent in developed economies and emerging economies---dispersed ownership, concentrated ownership of family, and concentrated ownership of the state. Because these ownership structures may exist in both well-developed and under-developed national governance systems, we match the types of ownership and the development of national governance system and obtain six different combinations, as shown in Table 1. The governance role of outside directors is likely to vary across configurations of the governance bundle. 


\section{Outside Directors as a Governance Mechanism}

Corporate governance literature indicates that outside directors generally serve two functions: managerial monitoring and resource provision (Hillman \& Dalziel, 2003;

Sundaramurthy \& Lewis, 2003). Monitoring is emphasized in agency theory, which posits that outside directors monitor decision making by managers who may act to maximize their selfinterests (Fama, 1980; Jensen \& Meckling, 1976). The resource provision function is more consistent with a resource dependence perspective. Taking advantage of their expertise, knowledge, skills, and ties to external organizations, directors provide a firm with advice and counseling, information channels with external organizations, access to external resources, and legitimacy, thereby enhancing firm performance (Pfeffer \& Salancik, 1978).

Outside directors need to calculate the benefits and costs related to the engagement in specific roles. From an agency theory perspective, a well-developed national governance system increases the litigation cost and reputation cost of outside directors' negligence in fulfilling monitoring role (Davis, 2002; Hartley, 2009), but reduces information cost and hence facilitates timely provision of advice and needed resources (Aguilera, et al, 2008). Thus, outside directors are likely to engage in both monitoring and resource provision in such a context. In contrast, they may have weak incentives to fulfill these obligations in an under-developed national governance system because they bear little costs for playing an ineffective governance role and the considerable information asymmetry further depresses their incentives. 
From a sociological perspective, outside directors' interactions with corporate leaders engender various social benefits and social costs that may influence those directors' willingness to fulfill their obligations. On one hand, providing advice and resources to corporate managers may be regarded as ingratiatory behavior that is likely to invoke those managers and also dominant owners to return a favor to outside directors. For instance, prior research indicates that directors who engage in ingratiatory behavior toward dominant owners are more likely to gain recommendations for board appointments at other firms (Westphal \& Stern, 2006, 2007). Such norm of reciprocity is likely to motivate outside directors to engage in resource provision. On the other hand, managerial monitoring may induce social costs that discourage outside directors to play the monitoring role. First, strong oversight and control lead to negative feelings and social distance between managers and directors (Gulati \& Westphal, 1999; Sitkin \& Roth, 1993), because managers view such behavior as a hostile signal. Outside directors who closely monitor and challenge the CEOs are often punished through social distancing in the U.S. context (Westphal \& Khanna, 2003). For example, they may have little chance to be invited to informal meetings and their advice is less likely to be solicited and adopted at formal meetings. They are also effectively sanctioned in the director labor market as indicated by the decreased chance of additional board appointments (Westphal \& Stern, 2007). Second, strong monitoring may result in "generalized retaliation" by CEO-directors (Westphal \& Zajac, 1997). CEOs who were subjected to increased board control at their home companies retaliate by promoting greater board independence and control at firms where they serve as outside directors, thus reducing fellow CEOs' power and influence. In light of such reciprocal retaliation, CEO-directors are not likely to engage in managerial monitoring so as to avoid future retaliation. 
We analyze in the following how the trade-off between the foregoing benefits and costs arising from national governance systems and corporate ownership structures shape outside directors' willingness to monitor management and provide resources in the six different contexts displayed in Table 1. Our analysis also engenders a new taxonomy of corporate governance systems based on configurations of the proposed governance bundle.

\section{CORPORATE GOVERNANCE BUNDLES AND ROLES OF OUTSIDE DIRECTORS}

\section{Dispersed ownership in under-developed national governance systems}

In firms with dispersed ownership structure, their ownership is often dominated by portfolio-oriented institutional investors, with ownership stakes of typically less than 3\% per investor (Barker, 2006). Examples of firms controlled by institutional owners include Kaufman \& Broad and Rexel in France, and Vedanta Resources in the U.K. When ownership is diffused, it is difficult for dispersed shareholders to coordinate their monitoring activities and is not worthwhile for each investor to monitor the company on a continuing basis due to the free-rider problem (Aguilera, 2005; Davies, 2002; Grossman \& Hart, 1980). Consequently, the problem of misalignment of interests between shareholders and managers arises, with managers and shareholders having different degrees of access to firm-specific information, and strong managers engaging in self-serving activities that may be detrimental to shareholders' wealth maximization.

To reduce the agency costs, institutional investors are likely to depend on board of directors, especially outside directors, in monitoring the management. Outside directors are not related to the firms and thus can be more assertive than inside directors when questioning and challenging managerial decisions (Johnson, Daily, \& Ellstrand, 1996; Mallin, 2007). At the same 
time, firms without controlling owners are also likely to rely on outside directors to extract resources and advice from their human and social capital, which can help managers make qualified decisions and also utilize resources provided by those directors to create competitive advantages (Hillman \& Dalziel, 2003). Therefore, firms with dispersed ownership are likely to value outside directors' engagement in both monitoring and resource provision functions equally. This creates an environment in which outside directors are more willing to engage in their governance roles.

However, outside directors embedded in an under-developed national governance system are less likely to engage in their governance roles because the poor legal protection constrains their incentive and ability to utilize their human capital and social capital when monitoring management and providing resources. In spite of financial incentives and the credible threat of lawsuits if they fail to exercise control (Westphal \& Khanna, 2003), outside directors in such a context may still lack strong incentives to monitor management for several reasons. First, in a national governance system with weak investor protection, it is less likely for dispersed owners to sue outside directors primarily due to their difficulty in meeting the demanding standards of the minimum percentage and period of shareholding to bring a lawsuit against directors. As in the case of China, for example, a shareholder is not able to sue directors for misconduct unless the shareholder has individually or collectively held more than $1 \%$ of the shares of the company for more than 180 consecutive days (Tang, 2008). As a result, outside directors are less likely to experience lawsuits and related financial penalties and reputational losses arising from corporate fraud. Second, in a weak national governance system where the obligations and rights of board and manager are not articulated or enforced properly, outside directors actively engaging in monitoring may suffer from more severe social distancing and retaliation imposed by managers, 
which can adversely affect their job security and career advancement. In addition, outside directors need to have the supporting information if they are to identify and vote against an inferior project proposed by managers (Raheja, 2005). Such verification costs tend to be high due to the lack of public information disclosure and the intentional concealment of information by insiders.

The under-developed national governance system may also inhibit outside directors from providing resources and counseling to the management. When facing poor legal protection of their interests (La Porta et al., 1999), investors are more reluctant to invest in firms, so outside directors are expected to provide legitimacy to enhance investors' confidence in the firms. However, to protect their managerial autonomy, strong managers tend to purposefully restrict information from outside directors and keep them out of the inner circle of decision-making, making it difficult for those directors to provide useful advice. Moreover, the relatively low scrutiny by dispersed owners will likely make outside directors less motivated to provide advice and resources. Additionally, given the low takeover risk in the weak market for corporate control, the provision of resources and counsel is less critical to prevent takeover. Such an ingratiatory behavior is therefore valued less by corporate owners and might not induce additional appointment on boards of other firms. Therefore, outside directors' incentive to provide benefits from their social networks for focal firms tend to be highly constrained in under-developed national governance systems. Accordingly, we propose

Proposition 1a: In firms with dispersed ownership in an under-developed national governance system, outside directors will engage little in either managerial monitoring or resource provision. 


\section{Dispersed ownership in well-developed national governance systems}

Well-developed national governance contexts such as the U.S. and the U.K. create a favorable environment for outside directors to fulfill their board tasks. This is particularly salient in promoting managerial monitoring. On one hand, the threat of lawsuits from the institutional investors is prominent if outside directors cannot fulfill their responsibility in monitoring. Under the U.S. law, a breach of care claim will result in dollars out of the director's pocket (Davis, 2002). Although director liability insurance is common, the threat remains credible because insurance does not cover criminal charges and the cost of unsuccessfully defending against charges of fraud arising from shareholder lawsuits (Hartley, 2009). Hence, outside directors are under high pressure from laws and regulations to conduct effective monitoring. Moreover, in the presence of effective market for corporate control, outside directors' ineffective monitoring and the consequent fraud or business failure will lead to the loss of investors and even takeover. These highly salient consequences expose outside directors to wide publicity and induce high reputation costs for them. On the other hand, high transparency leads to enhanced publicity, heightened regulatory scrutiny, and more attention to the appointment, evaluation, and removal of outside directors (DeMott, 2007), thus protecting those directors from strong managers' and inside board members' arbitrary treatment and social distancing. As a result, outside directors in well-developed national governance systems bear lower litigation, reputation and social costs of conducting managerial monitoring, and thus are more likely to engage in managerial monitoring.

Moreover, a well-developed national governance system may enhance monitoring by offering institutionalized channels of information disclosure and sharing. Exchange partners follow formal rules and regulations that stipulate each partner's rights and responsibilities, and 
are required to disclose the relevant and key information to transaction partners (North, 1990). Market intermediaries also play active role in providing quality and timely information (Rajan, 1992; Von Thadden, 1995). Such institutionalized information disclosure and sharing enable outside directors to reduce their reliance on personal relationships with managers to secure information and thus to mitigate uncertainty and managerial opportunism. As a result, outside directors are able to maintain independence from the management and exercise substantial discretion in their managerial monitoring activities with lower information cost.

The well-developed national governance system is also likely to stimulate outside directors to provide resources and advice for three reasons. First, as in the case of monitoring role, the national governance system imposes higher litigation cost and reputation cost for directors when they fail to fulfill their advisory role. In addition, in well-developed governance systems where information is transparent and capital market reflects corporate performance efficiently, outside directors' outstanding performance in resource provision can enhance their reputation and thus induce a fellow director's recommendation for a board seat at another company (Westphal \& Stern, 2007). Failure to fulfill their resource provision role may in turn damage their reputation and legitimacy in the director labor market. Second, the management of firms with dispersed ownership structure tends to drive outside directors to provide resources. Given the goal of maximizing financial gains from a portfolio of investments, dispersed institutional investors are more concerned about maximizing shareholder value and liquidity than other types of owners (Aggarwal et al. 2010; Thomsen \& Pedersen 2000), and are inclined to sell the shares of the under-performing company (Hirschman, 1970; Ingley \& Van Der Walt, 2004). Hence, to minimize takeover threats, managers are likely to seek advice and resources from outside directors to enhance firm performance. Firms that are under strong government 
regulations might also rely on outside directors with connections to regulatory authorities (Che, 1995; Geiger, Lennox \& North, 2008). For example, firms might use outside directors as a means to facilitate the acquisition of external resources such as government licenses, permits and contracts that are critical for the firm's success (Goldman, Rocholl, \& So, 2009). We therefore argue that outside directors are likely to engage in both managerial monitoring and resource provision in this context.

Proposition 1b: In firms with dispersed ownership in a well-developed national governance system, outside directors will engage in managerial monitoring and resource provision to a great extent.

\section{Family ownership in under-developed national governance systems}

Compared to dispersed owners, large and block shareholders have much stronger incentives to monitor managers because of their significant economic stakes (Shleifer \&Vishny, 1986). Blockholders also have the power to limit management discretion and ensure that decisions made by managers are accountable to shareholders by accessing private value-relevant information (Heflin \& Shaw, 2000), engaging in corporate policy making with management (Bhagat, Black \& Blair, 2004; Denis \& McConnell, 2003), imposing influence on voting, and drawing special attention from management (Useem, 1996). Therefore, blockholders can substitute outside directors in monitoring management. The extent to which firms emphasize outside directors' resource provision role will likely depend on the blockholders' resource endowment.

Among the various blockholders, family owners are characterized by focused portfolios, a long-term orientation, great risk aversion, pursuit of both financial returns and socio-emotional 
wealth, and family members' possession of senior management positions (Gómez-Mejía et al., 2007; Hamilton \& Kao, 1990; Shleifer \& Vishny, 1997). Examples of family-owned firms include Samsung Group in Korea, Formosa Group in Taiwan, Oracle Corp. in the U.S., and BMW in Germany. The controlling families' significant ownership stakes in the firms and active involvement in management enable them to effectively monitor the management and make sure that they take actions to maximize family wealth or to satisfy socio-emotional wealth of family owners. Therefore, the controlling family may substitute outside directors in managerial monitoring, making those directors play a trivial monitoring role. Indeed, Jaggi, Leung, and Gul (2009) find that the monitoring effectiveness of independent boards is lower in family-controlled firms than in non-family-controlled firms. In contrast, the controlling family likely prioritizes outside directors' resource provision role. The concentrated family equity holdings result in a relative lack of financial portfolio diversification and limited liquidity (Anderson \& Reeb, 2004), making resources available to family owners limited as compared to other blockholders such as the state and the institutional investors. Moreover, viewing the family business as a vehicle for family fortune, family stature in the society and the careers of succeeding generations, the controlling families do their utmost to maintain firm viability over long-term (Miller \& BretonMiller, 2005). As a result, family-owned firms are likely to prefer prospective outside directors that can generate valuable resources for them.

The imbalance between outside directors' two roles in family-owned firms becomes particularly salient when the national governance system is under-developed. The lack of information provided by the firm and market intermediaries makes outside directors highly reliant on internal information sources to play their monitoring role (Luo \& Chung, 2013). However, in family-owned firms, managers with particularistic ties with the controlling family 
(e.g., family and prior social ties) form an inner circle which is a typical leadership structure that sets the course of planning and development of firms (Hamilton \& Kao, 1990). These managers are endowed with great decision-making power because they are loyal to the family and embrace the controlling family's authority wholeheartedly (Luo \& Chung, 2005). The close interplay between family and inner-circle managers may lead to limited information disclosure to outside directors because 'families tend to guard their privacy, and are very careful with whom they share confidential information’ (Lester \& Cannella, 2006: 762). Moreover, in family-owned firms, control may be exercised directly - for example through the removal and replacement of directors when the controlling shareholder has the requisite voting power-or indirectly, for example through explicit or implicit threats to remove insubordinate directors, without concerning about the unwanted attention from regulatory scrutiny and publicity in a less transparent national governance system. These attributes of family ownership and weak national governance system significantly increase the information cost and social cost for outside directors, thus constraining their ability to monitor the management. The limited influence of outside directors is well illustrated in the case of Xinyi Science and Technology Company in Taiwan. The firm's outside director, Chen-en Ko (a renowned accounting professor), resigned before the firm's illegal tunneling was brought to court because he was not able to stop the leaders from expropriating outside shareholders and did not want to continue his appointment (Luo \& Chung, 2013).

In contrast, outside directors of family-owned firms are likely to play an active role in providing external resources to managers. In an area where contract enforcement laws are not well developed and markets are less efficient, personal contacts become important (Peng \& Heath, 1996; Xin \& Pearce, 1996). Family owners, caring about their wealth, welcome outside 
directors for their connections. In turn, by fulfilling a resource provision role, outside directors will gain support from the family owners and inside managers, minimizing the social distancing while increasing employment opportunity in the future. Anecdotal evidence shows that the founding families of Taiwanese business groups usually invite legislators and former government officials to sit on the board so that they can derive benefits such as bank loans, preferential business treatment, government contracts and entry permits, from their connections with the government (Wealth Magazine, 2002). They also tend to have better understanding of government policy and thus make wise decisions under the guidance of government-linked directors. Following this line of discussion, we propose:

Proposition 2a: In firms with family controlling shareholders in an under-developed national governance system, outside directors will engage in resource provision rather than managerial monitoring.

\section{Family ownership in well-developed national governance systems}

In a well-developed national governance system, outside directors of family-owned firms are likely to play a more balanced role in monitoring and resource provision primarily due to the higher pressures placed on the board by external capital markets, legal system, and the consequent reduced family dominance in corporate governance. Well-developed national governance systems, especially systems of the U.S. and the U.K., emphasize transparency, disclosure, the separation of ownership from control, and professionalism. In such systems, information disclosure is more effective meaning that outside directors can get information not only from external market intermediary, but also from institutionalized internal sharing (Ravina \& Sapienza, 2009). The social cost of monitoring is also lower because family owners are 
reluctant to induce enhanced negative publicity, heightened regulatory scrutiny, and other unwanted attention in their attempt to remove directors (DeMott, 2007). In addition, familyowned firms in such systems may suffer from an increasing loss of legitimacy when the family's role in corporate governance increases and when managers with relationships with the family are hired because these practices contradict the prevailing norms and practices of good corporate governance. The compromised legitimacy of family-owned firms can adversely affect firms' financial returns (Bansal \& Clelland, 2004) and further damage family’s socio-emotional wealth. To mitigate such adverse consequences, family owners are likely to encourage outside directors to perform board duties adequately.

However, we speculate that these outside directors are likely to engage more in resource provision than in managerial monitoring because of controlling families' strong incentive for and intense involvement in monitoring the management. When family owners serve as managers, the strong alignment of interests between owners and managers substantially reduces their reliance on outside directors to monitor management (Garcia \& Garcia, 2010). The substitutability between outside directors and family owners in monitoring management enables outside directors to pay more attention to resource provision. Given the efficient director labor market, outside directors' ingratiatory behavior such as provision of advice and resources is likely to be rewarded by family owners and hence such behavior increases their chance of being appointed at other boards. Moreover, despite the better protection of minority shareholders in such a governance bundle, the fundamental agency problem between the controlling family and minority shareholders can still lead to limited information disclosure and transparency and thus constrain outside directors' ability to monitor the management. For example, family firms within 
the S\&P 500 in the U.S. make less disclosure about corporate governance practices than do nonfamily firms (Ali, Chen, \& Radhakrishnan, 2007). Therefore, we posit:

Proposition 2b: In firms with family controlling shareholders in a well-developed national governance system, outside directors will engage more in resource provision than in managerial monitoring.

\section{Concentrated state ownership in under-developed national governance systems}

State ownership is prevalent around the world. In an analysis of Forbes Global 2000 list of the world's largest 2000 public companies in the business year 2010-2011, Kowalski et al. (2013) revealed that 21 out of 38 OECD countries have a country state-owned enterprises (SOE) share higher than zero, with China, the United Arab Emirates, Russia, Indonesia, Malaysia, Saudi Arabia, India, Brazil, Norway and Thailand being the ten countries with the highest country SOE shares. The report indicated the five sectors with the highest state shares, including mining support activities, civil engineering, land transport and transport via pipelines, mining of coal and lignite, and the extraction of crude petroleum and gas.

The key agency problem in state-owned firms is that the state may expropriate minority shareholders' interests. Unlike other blockholders, the state is not only the controlling shareholders of state-owned firms, but also regulators that bear the responsibility to balance multiple goals, such as maximizing firm profitability, securing social welfare, and protecting strategic sectors from foreign competition (Shleifer \& Vishny, 1994, 1998; Vickers \& Yarrow, 1989). Under certain circumstances, the state owners may pursue non-profit goals at the expense of minority shareholders. For instance, state-owned firms are less likely to reduce redundant employees than private firms due to their obligation to help the government maintain 
unemployment rate low. Although in theory the tax-paying public owns state-owned firms, those firms are effectively controlled by bureaucrats or politicians who can manipulate resources of the firms to pursue their personal interests, such as securing votes by catering for the interests of special interest groups (Shleifer \& Vishny, 1997). Hence, neither profitability nor minority shareholders' interest is likely to be the first priority in state-owned firms. At the same time, by undertaking parallel functions as owner and regulator (Aguilera et al., 2011), state owners can easily override the regulatory system and acquire external resources. With abundant resources available and the pursuit of autonomy and power in making corporate policies, the state owners tend to pay little attention to outside directors and often view them as "rubber stamps" that are not supposed to either monitor management or provide resources.

In addition, in an under-developed national governance system, outside directors of stateowned firms have even weaker incentive and power to execute their monitoring. With underdeveloped information disclosure regulations, the state owners are able to shield important information from outside directors. For example, when the government subsidizes state-owned firms in certain strategically important sectors, it usually requires the bureaucrat executives to keep the information within insiders (Eldomiaty \& Choi, 2006). Without access to such important information, outside directors will not be able to monitor the management effectively. Furthermore, considerable evidence shows that social distancing is more pronounced as a result of deviant behavior in groups that are socially cohesive because of demographic homogeneity and/or network ties among members (Coleman, 1994; Merry, 1984; Scott, 1976; Westphal \& Khanna, 2003; Wood, 1974). In a state-owned firm, politicians and politically connected directors who share the same interests and ideology often dominate the board. Hence, outside directors engaging in monitoring are likely to suffer from higher levels of social distancing from 
the socially cohesive state owners and inside board members. This is particularly the case when minority shareholders are not well protected and blockholder's power is not effectively restricted. Powerful blockholders can easily vote to remove outside directors, or informally exclude those directors from the decision making process, thus forcing such directors to resign. Therefore, outside directors are not likely to play an active monitoring role in state-owned firms in an under-developed national governance system due to the high information cost and social cost.

In such a context, outside directors' function of resource provision is likely to be compromised as well. In the absence of well-developed regulations on information disclosure and investor protection, being the de facto owner, the state can easily bail out its company by providing resources such as subsidy, credit, information and other forms of protection at the expense of minority shareholders (Aharoni, 1986). The necessity of having outside directors to acquire external resources is therefore low. Further, confronting the inefficient capital markets and concomitant low pressure from minority shareholders, the state owner and managers have little incentive to seek for outside directors who can provide valuable resources and advice on how to improve firm performance. Moreover, with disclosure regulations absent or poorly enforced, state owners (i.e., bureaucrats) can purposefully hide critical information from outside directors so as to pursue personal or public goals that deviate from or even contradict with minority shareholders' goal of profit maximization. The limited information available makes outside directors unable to provide necessary resources and useful advice timely. Liao, Young and Sun (2009) find that in China, listed state owned firms are motivated to organize a small, insider-controlled board, thus keeping key information and decision making out of the reach of outside directors. Hence, the boards of many Chinese state-owned enterprises (SOE) serve as 
either the conduit board, which simply relays directions given by ministers, or the symbolic board, which is circumvented and uninvolved, making the SOE run as an extension of a government department (Frederick, 2011). Therefore, we present the following proposition:

Proposition 3a: In firms with state controlling shareholders in an under-developed national governance system, outside directors will engage little in managerial monitoring or resource provision.

\section{Concentrated state ownership in well-developed national governance systems}

In a well-developed national governance system where the board's responsibility to facilitate information disclosure is stipulated and the capital market functions efficiently, the regulatory and market pressures on outside directors to fulfill their monitoring role are likely to outweigh the opposite pressure from state owner, and thus provide them with strong incentives to monitor the management. Meanwhile, a well-developed national governance system may force the state owners to disclose critical corporate information through various channels, such as board meetings, stock market and the market for corporate control. The resulting transparent information will enhance managerial monitoring by outside directors. Moreover, the attractiveness of outside directors on the director labor market depends on their competence of protecting investors and fulfilling their monitoring obligations. The chance of being revenged by the state owners and inside directors is hence likely low when those directors exercise their monitoring obligation. Recent examples of Chinese state-owned firms in Hong Kong provide a vivid illustration of how the state owners may be forced to allow its board directors to play an active monitoring role in a well-developed governance system. Unlike Mainland China, Hong Kong maintains high corporate governance standards and has developed a sophisticated legal 
system to well protect shareholders. Although enterprises from Mainland China were at the bottom of the list in terms of corporate governance in 2003 (Li, 2012), a study in 2012 shows that six of the top-ten firms with the best corporate governance practices in Hong Kong are stateowned or backed by state-owned enterprises from Mainland China, such as the Bank of China, China COSCO, China Life, CNOOC, ICBC, and Lenovo Group (Zhang, 2012). As suggested in the study, this significant improvement is mainly attributed to the well-developed corporate governance system in Hong Kong, which stimulates the large state-owned enterprises to devote time and efforts to improving transparency and clarifying the rights and responsibilities of boards of directors. This implies that outside directors in state-owned firms are likely to fulfill their monitoring role in such environment.

However, even in a well-developed national governance system, state-owned firms may still enjoy preferential treatments and privileges in obtaining resources. This reduces their reliance on outside directors for accessing external resources and lowers their emphasis on such directors' role to establish a linkage to external organizations. Instead, outside directors are more likely to engage in managerial monitoring. As a result, outside directors in such a governance bundle are likely to focus more on managerial monitoring than on resource provision because of the relatively high external pressures for effective corporate governance and low internal demand for resource acquisition and provision. Accordingly, we propose:

Proposition 3b: In firms with state controlling shareholders in a well-developed national governance system, outside directors will engage more in managerial monitoring than in resource provision.

\section{DISCUSSION AND CONCLUSION}


We began by noting that outside directors are embedded in a multi-level governance system and that their primary roles (monitoring or resource provision) are not independent from the context in which focal firms operate. Drawing upon research on the board of directors and governance bundle, we argue that the roles of outside directors are determined by their interplay with other components in the corporate governance bundle composed of national governance system and corporate ownership structure. We further develop a taxonomy of corporate governance systems on the basis of six distinct configurations of national governance system, corporate ownership structure, and outside directors.

Our work contributes to the literature on board governance and on comparative corporate governance. Our focus on the governance bundle in which outside directors are embedded sheds additional light on the antecedents and outcome of their governance behavior in the boardroom. In the agency theory framework, outside directors are expected to play an independent monitoring role (Fama, 1980). From the resource dependence perspective, those directors are viewed as resource providers who leverage their human and social capital to enhance organizational performance (Pfeffer \& Salancik, 1978). However, these perspectives disregard other governance mechanisms with which the board and individual directors interact and the impacts of such interaction on their behavior. We highlight the importance of understanding the board roles from a governance bundle perspective (Aguilera et al., 2011). In particular, we suggest that outside directors may not be always interested in engaging in managerial monitoring. Instead, the importance of outside directors in managerial monitoring is contingent on the combination of other governance mechanisms in a governance bundle. By the same token, the resource provision role of outside directors may also be promoted or constrained by the governance bundle in which they are embedded. In essence, this study emphasizes the 
importance of considering the fitness between outside directors' roles and other governance mechanisms when studying the functions of board of directors.

Further, our work contributes to the comparative corporate governance research by offering a new multi-level governance taxonomy, in which the national governance system and corporate ownership structure are explicitly separated but simultaneously considered. Going beyond the prior taxonomies that lump together ownership structure and national governance system and focus predominantly on industrialized countries (e.g., Aguirela et al., 2011; Franks \& Mayer, 1990, 2001; Millar et al., 2005), the newly developed taxonomy provides a more finegrained categorization of corporate governance bundles. In particular, we advance the understanding of cross-national variation in corporate governance systems around the world by differentiating types of owners and their strategic objectives not only in developed economies, but also in transition and emerging economies.

This paper also provides some insights on why the board has been decoupling its activities from the codes on book in some countries. Agency theory suggests that outside directors are expected to play a more effective role in corporate governance than inside directors because of their independence. However, real business stories inform us that outside directors do not necessarily engage in their roles as the formal regulatory system expects in both developed and developing economies. The behavior of outside directors potentially constitutes a typical decoupling case, in which the formal policies and structures are regularly decoupled from an organization's actual internal practices and routines (Meyer \& Rowan, 1977). This paper suggests that decoupling takes place mainly because of differences in cross-firm ownership structure and cross-national governance systems. With their dominant power and certain strategic 
goals, some blockholders are able to constrain the monitoring and resource provision activities of outside directors, making those directors merely a ceremonial existence in some contexts. At the same time, blockholders, managers, and outside directors interact within a national governance system where the effectiveness of legal and regulatory enforcement (North, 1990) and the capital market efficiency vary among countries. The differences in national governance systems hence also contribute to the varying degrees of decoupling of outside directors' roles among countries (Edelman, 1992).

We discuss outside directors without differentiating independent directors and affiliated directors because our arguments about how the regulatory pressure from the national governance system and the social pressure from the owners, managers and peers affect director behavior apply to both of them, although the relative importance of the two pressures may slightly differ between them. Moreover, the definition of the independence of a director varies across countries and over time. General definitions of independence for public-company directors focus on criteria indicative of a director's independence from the company's management. More specific criteria include a direct employment relationship, a non-employment business relationship under which the director or an affiliate has received substantial payments from the corporation, a family relationship with an executive officer of the corporation, or service as an executive officer of another entity with which the corporation has an economically material relationship (DeMott, 2007). Moreover, managers and outside directors may have social ties (Hwang \& Kim, 2009) and develop friendship along the way of frequent counseling and advice (Westphal, 1999). Future empirical research that examines the different roles of outside directors should make clear distinctions between independent and non-independent outside directors that are appropriate in each institutional context. 
Our work also holds important practical implications. First of all, as the board functions differently depending on the specific configuration of governance bundle in which it is involved, the imposition of a successful foreign governance model does not necessarily lead to desirable outcomes. But as suggested in our model, outside directors are generally more engaged in managerial monitoring and resource provision in well-developed national governance systems than in under-developed ones. Therefore, to encourage outside directors to engage more in specific roles, the government needs to advance the national governance system and create a favorable environment that promotes desirable director behaviors. Future research may include other types of blockholders, such as foreign investors and strategic investors, and other firmlevel governance mechanisms, such as compensation of directors and managers, to develop a more comprehensive understanding of corporate governance bundles. Another interesting direction for future research is to predict the potential convergence of governance models across countries driven by the development of national governance systems and the change in dominant ownership structures (Yoshikawa \& Rasheed, 2009). For example, future research may investigate how the role of boards will change in emerging economies such as China and Brazil, as a result of substantial changes taking place in the regulatory regimes and the declining significance of state ownership in the economy.

Second, this paper offers implications for the advancement of outside directors' career. Fama and Jensen (1983: 315) conjecture that "outside directors have incentives to develop reputations as experts in decision control... They use their directorships to signal to internal and external markets for decision agents that they are decision experts." A number of studies have supported their hypothesis by showing evidence that outside directors who provide effective monitoring or advisory services gain additional outside directorships (Coles \& Hoi, 2003; Farrell 
\& Whidbee, 2000; Harford, 2003; Yermack, 2004). Our work suggests that for outside directors to improve their career prospects, they should first identify the preferences of different types of controlling shareholders in their specific national context and then develop their expertise and social networks correspondingly. It might be interesting for future research to examine how outside director' human capital and social capital are developed and embedded in the governance bundle involved. We hope that our conceptual framework will motivate further research to enrich our understanding of the functioning of the board in various governance systems. 


\section{REFERENCES}

Adams, R.B., Hermalin, B.E., \& Weisbach, M.S. 2010. The role of boards of directors in corporate governance: A conceptual framework and survey. Journal of Economic Literature, 48(1): 58-107.

Adams, Renée B., \& Ferreira, D. 2007. A theory of friendly boards, Journal of Finance. 62, 217 250.

Aggarwal, R., Isil, E., Miguel, F., \& Matos, P. 2010. Does governance travel around the world? Evidence from institutional investors. Journal of Financial Economics, 100(1): 154-181.

Aguilera, R.V., \& Jackson, G. 2003. The cross-national diversity of corporate governance: Dimensions and determinants. Academy of Management Review, 28(3): 447-465.

Aguilera, R. V., Filatotchev, I, Gospel, H, \& Jackson, G. 2008. Contingencies, complementarities, and costs in corporate governance models. Organization Science, 19 (3): 475-492.

Aguilera, R.V., Desender, K., \& Castro, L. R. K. 2011. A bundle perspective to comparative corporate governance. In Clarke, T. and D. Branson (Eds.), SAGE Handbook of corporate governance. New York: Sage Publications. http://papers.ssrn.com/sol3/papers.cfm?abstract_id=1806525.

Aguilera, R.V. 2005. Corporate governance and director accountability: An institutional comparative perspective. British Journal of Management, 16: 39-53.

Aharoni, Y. 1986. The evolution and management of state owned enterprises. Ballinger Pub. (Melrose, MA)

Ali, A., Chen, T.Y., \& Radhakrishnan, S. 2007. Corporate disclosures by family firms. Journal of Accounting and Economics. 44: 238-286.

Anderson, R., \& Reeb, D. 2004. Board composition: Balancing family influence in S\&P 500 firms. Administrative Science Quarterly, 49, 209-37.

Bansal, P., \& Clelland, I. 2004. Talking trash: Legitimacy, impression management and unsystemastic risk in the context of the natural environment. Academy of Management Journal, 47: 93-103.

Barca, F., \& Becht, M. 2001. The control of corporate Europe, eds. Oxford University Press, Oxford. 
Barker, R.M., 2006. Insiders, outsiders, and change in European corporate governance, Council for European Studies Conference, Chicago, March 31, 2006. http://councilforeuropeanstudies.org/files/papers/Barker.pdf

Bhagat, S., Black, B., \& Blair, M. 2004. Relational investing and firm performance. Journal of Financial Research, 27(1): 1-30.

Black, B., \& Kraakman, R. 1996. A Self-Enforcing Model of Corporate Law. Harvard Law Review, 109: 1911-82.

Black, B. 2001. The legal and institutional preconditions for strong stock market, UCLA Law Review, 48: 781-858.

Carter, C.B., \& Lorsch, J.W. 2004. Back to the drawing board: Designing corporate boards for a complex world. Boston: Harvard Business School Press.

Che, Y.K. 1995. Revolving doors and the optimal tolerance for agency collusion, RAND Journal of Economics, 26: 378-397

Coffee, J.C. 1999. The future as history: The prospects for global convergence in corporate governance and its implications, Northwestern University Law Review, 93: 641-707.

Coleman, J. S. 1994. Foundations of Social Theory, 2d ed. Cambridge, MA: Harvard University Press.

Coles, J., \& Hoi, C. 2003. New evidence on the market for directors: Board membership and Pennsylvania Senate Bill 1310, Journal of Finance, 58, 197-230.

Cornelius, R.K., \& Kogut, B. 2003. Corporate governance and capital flows in a global economy. Oxford University Press

CSRC (China Securities Regulatory Commission). 2001. Guidelines for introducing outside directors to the board of directors of listed companies. CSRC: Beijing. www.csrc.gov.cn

Dalton, D., Daily, C., Ellstrand, A., \& Johnson, J. 1998. Metaanalytic review of board composition, leadership structure and financial performance. Strategic Management Journal, 19: 269-290.

Davies, P.L. 2002. Board structures in the UK and Germany: Convergence or continuing divergence? International and Comparative Corporate Law Journal, 2(4): 435-56.

Davis, Jr. K.B. 2002. The director's duty of oversight-pre-Enron; post-Enron, Presented at the International Conference to Commemorate the Fortieth Anniversary of the Korean Commercial Code, Seoul, http://law.wisc.edu/m/jrjnz/oversight.pdf 
DeMott, D. A., 2007. Guests at the table: independent directors in family-influenced public companies. Duke Law School Faculty Scholarship Series. Paper 101. http://lsr.nellco.org/duke_fs/101.

Denis, D.K., \& McConnell, J.J. 2003. International corporate governance. The Journal of Financial and Quantitative Analysis. 38(1): 1-36.

Desender, K., Garcia-Cestona, M.A., Crespi, R, \& Aguilera, R.V. 2009. Board characteristics and audit fees: Why ownership structure matters? University of Illinois at Urbana-Champaign, College of Business, Working Paper, 0107. http://www.business.illinois.edu/Working_Papers/papers/09-0107.pdf.

Desender, K. A., Aguilera, R. V., Crespi, R., \& Garc'Ta-Cestona, M.A. 2013. When does ownership matter? Board characteristics and behavior. Strategic Management Journal, 34: 823-842.

Douma, S., Rejie, G., \& Rezaul, K., 2006. Foreign and domestic ownership, business groups, and firm performance: Evidence from a large emerging market. Strategic Management Journal, $27,637-657$.

Edelman, L.B. 1992. Legal ambiguity and symbolic structures: Organizational mediation of civil rights law. The American Journal of Sociology, 97:1531-1576.

Eldomiaty, T.I., \& Choi, C.J. 2006. Corporate governance and strategic transparency: East Asia in the international business systems. Corporate Governance: International Journal of Business in Society.6, Available at SSRN: http://ssrn.com/abstract=712261

Fama, E. 1980. Agency problems and the theory of the firm. Journal of Political Economy, 88: 288-307.

Fama, E. F., \& Jensen, M. C. 1983, Separation of ownership and control, Journal of Law and Economics, 26, 301-325.

Farrell, K., \& Whidbee, D. 2000. The consequences of forced CEO succession for outside directors, Journal of Business, 73, 597-627.

Filatotchev, I. 2008. Developing an organizational theory of corporate governance: Comments on Henry L. Tosi (2008) "Quo Vadis? Suggestions for future corporate governance research". Journal of Management and Governance, 12: 171-178.

Filatotchev, I., \& Nakajima, C. 2010. Internal and external corporate governance: An interface with an organization and its environment, British Journal of Management, 21(3): 591-606. 
Finkelstein, S., \& D'Aveni, R. 1994. CEO duality as a double-edged sword: How boards of directors balance entrenchment avoidance and unity of command. Academy of Management Journal, 37: 1079-1108.

Fiss, P. C., \& Zajac, E. J. 2004. The diffusion of ideas over contested terrain: The (non)adoption of a shareholder value orientation among German firms. Administrative Science Quarterly, 49: 501-534.

Franks J. \& Mayer C. 1990. Capital markets and corporate control: A study of France, Germany and the UK. Economic Policy, 5(10): 191-231.

Franks, J. \& Mayer, C. 2001. Ownership and control of German corporations. The Review of Financial Studies, 14 (4): 943-977.

Frederick, W. 2011. Enhancing the role of boards of directors of state owned enterprises. OECD Corporate Governance Working Papers, No. 2, OECD Publishing. http://dx.doi.org/10.1787/5kg9xfg6n4wj-en.

Garcia, O.M. \& Garcia, R.R. 2010. Family ownership, structure and board of directors effectiveness: Empirical evidence from European firms. $9^{\text {th }}$ Annual IFERA Conference, Lancaster, U.K.

García-Castro, R., Aguilera, R. V., \& Ariño, M. A. 2013. Bundles of firm corporate governance practices: A fuzzy set analysis. Corporate Governance: An International Review, 21 (4):390-407.

Geiger, M.A., Lennox, C.S., \& North, D.S. 2008. The hiring of accounting and finance officers from audit firms: how did the market react? Review of Accounting Studies, 13: 55-86.

Goldman, E., Rocholl, J., \& So J. 2009. Do politically connected boards affect firm value? The Review of Financial Studies, 22: 2231-2360.

Gómez-Mejía, L.R., Haynes, K.T., Núñez-Nickel, M., Jacobson, K.J.L., \& Moyano-Fuentes, J. 2007. Socioemotional wealth and business risks in family-controlled firms: Evidence from Spanish olive oil mills. Administrative Science Quarterly, 52: 106- 137.

Grossman, S., \& Hart, O. 1980. Takeover bids, the free-rider problem, and the theory of the corporation. The Bell Journal of Economics, 11:42-64.

Gulati, R., \& Westphal, J.D. 1999. Cooperative or controlling? The effects of CEO-board relations and the content of interlocks on the formation of joint ventures. Administrative Science Quarterly, 44: 473-506. 
Hamilton, G.G., \& Kao, C.S. 1990. The institutional foundation of Chinese business: the family firm in Taiwan. In C. Calhoun (Eds.), Comparative Social Research: 135-151. Greenwich: JAI.

Harford, J. 2003. Takeover bids and target directors' incentives: The impact of a bid on directors' wealth and board seats. Journal of Financial Economics 69, 51-83.

Hartley, T.C. 2009. International commercial litigation: Text, cases and materials on private international law. Cambridge University Press. The Edinburgh Building, Cambridge CB2 8RU, UK.Heflin, F., \& Shaw, K.W. 2000. Blockholder ownership and market liquidity. Journal of Financial and Quantitative Analysis, 35 (2000), 621-633.

Hillman, A.J., \& Dalziel, T. 2003. Boards of directors and firm performance: Integrating agency and resource dependence perspectives. Academy of Management Review, 28: 383-396.

Hirschman, A.O. 1970. Exit, voice, and loyalty: Responses to decline in firms, organizations, and states. Cambridge, MA: Harvard University Press. ISBN 0-674-27660-4 (paper).

Hoskisson, R.E., Castleton, M.W., \& Withers, M.C. 2009. Complementarity in monitoring and bonding: More intense monitoring leads to higher executive compensation. Academy of Management Perspectives, 23(2): 57-74.

Hwang, B.H., \& Kim, S. 2009. It pays to have friends. Journal of Financial Economics, 93: 138158.

Ingley, C.B., \& Van Der Walt, N.T. 2004. Corporate governance, institutional investors and conflicts of interest. Corporate Governance: an International Review, 14: 534-551.

Jacoby, S. M. 2005. The embedded corporation: Corporate governance and employment relations in Japan and the United States. Princeton: Princeton University Press.

Jaggi, B., Leung, S., \& Gul, F., 2009. Family control, board independence and earnings management: Evidence based on Hong Kong firms. Journal of Accounting and Public Policy. 28 (4), 281-300.

Jensen, M. C., 1988, Agency costs of free cash flow, corporate finance, and the market for takeovers. American Economic Review, 76, 323-329.

Jensen, M. C., \& Meckling, W. 1976. Theory of the firm: Managerial behavior, agency costs and ownership structure. Journal of Financial Economics, 3: 305-360.

Johnson, J. L., Daily, C. M., \& Ellstrand, A. E. 1996. Board of directors: A review and research agenda. Journal of Management, 22(3): 409-438. 
Kowalski, P., Büge, M., Sztajerowska, M., \& Egeland, M. 2013. State-owned enterprises: Trade effects and policy implications, OECD Trade Policy Papers, No. 147, OECD Publishing. http://dx.doi.org/10.1787/5k4869ckqk7l-en

La Porta, R., Lopez-de-Silanes, F., Shleifer, A., \& Vishny, R., 1997. Legal determinants of external finance. Journal of Finance, 52, 1131-1150.

La Porta, R., López-de-Silanes, F., Shleifer, A., \& Vishny, R. 1998. Law and finance, Journal of Political Economy, CIV, 1113-1155.

La Porta, R., López-de-Silanes, F., \& Shleifer,A. 1999. Corporate ownership around the World, Journal of Finance, 54 (2), 471-518.

La Porta, R., Lopez-de-Silanes, F., Shleifer, A., \& Vishny, R. 2000. Investor protection and corporate governance. Journal of Financial Economics, 58(1-2): 3-27.

Lester, R.H., \& Cannella, A.A. 2006. Interorganizational familiness: How family firms use interlocking directorates to build community-level social capital. Entrepreneurship Theory and Practice, 30, 755-775.

Levine, R., \& Zervos, S. 1996, Stock markets, banks and economic growth, working paper, The World Bank, Washington, DC.

Levine, R. 1998, The legal environment, banks, and long-run economic growth, Journal of Money, Credit and Banking, 30(3): 596-613.

Li, T. 2012. State-owned mainland companies top in corporate governance study. China Daily. HK. Edition. http://www.chinadaily.com.cn/hkedition/2012-11/21/content_15946380.htm.

Liao, J., Young, M. R., \& Sun, Q. 2009. The advisory role of the board: Evidence from the implementation of independent director system in China. Massey U. College of Business Research Paper No. 1. Available at SSRN: http://ssrn.com/abstract=1361202 or http://dx.doi.org/10.2139/ssrn.1361202.

Luo, X, \& Chung, C.N. 2005. Keeping it all in the family: The role of particularistic relationships in business group performance during institutional transition. Administrative Science Quarterly, 50: 404-439.

Luo, X.R. \& Chung, C.N. 2013. Filling or abusing the institutional void? Ownership and management control of public family businesses in an emerging market. Organization Science, 24(2): 591-613.

Mallin, C. A. 2007. Corporate governance. New York: Oxford University Press. 
Martynova, M., \& Renneboog, L.D.R., 2010. A corporate governance index: Convergence and diversity of national corporate governance regulations, Discussion Paper 2010-17, Tilburg University, Center for Economic Research.

Merry, S. E. 1984. Rethinking gossip and scandal. In D. Black (ed.), Toward a general theory of social control, 1:271-296. London: Academic Press.

Meyer, J., W., \& Rowan, B. 1977. Institutionalized organizations: Formal structure as myth and ceremony. The American Journal of Sociology, 83(2): 340-363.

Millar, C.C.J.M., Eldomiaty, T.I., Choi, C.J., \& Hilton, B. 2005. Corporate governance and institutional transparency in emerging markets. Journal of Business Ethics, 59: 163-174.

Miller, D., \& Breton-Miller, I. 2005. Managing for the long run: Lessons in comparative advantage from great family business. Boston, MA: Harvard Business School Press.

Moore, C.B., Bell, R.G., Filatotchev, I. \& Rasheed, A.A. 2012. Foreign IPO capital market choice: Understanding the institutional fit of corporate governance. Strategic Management Journal, 33(8): 914-937.

Morck, R., Wolfenzon, D., \& Yeung, B. 2005. Corporate governance, economic entrenchment and growth. Journal of Economic Literature, 43(3): 655-720.

North, D. C. 1990. Institutions, institutional change and economic performance, Cambridge: Cambridge University Press

Peng, M., \& Heath, P.S. 1996. The growth of the firm in planned economies in transition: institutions, organizations, and strategic choice. Academy of Management Review. 21: 492528.

Peng, M.W. 2004. Outside directors and firm performance during institutional transitions. Strategic Journal of Management, 25: 453-471.

Peng, M.W., Tan, J. \& Tong, T.W. 2004. Ownership types and strategic groups in an emerging economy. Journal of Management Studies, 41(7): 1105-1129.

Pfeffer, J., \& Salancik, G.R. 1978. The external control of organizations. New York: Harper \& Row.

Pistor, K., Raiser, M. \& Gelfer, S. 2000. Law and finance in transition economies, Economics of Transition, 8(2): 325-68.

Raheja, G.C., 2005, Determinants of board size and composition: A theory of corporate boards, Journal of Financial and Quantitative Analysis, 40, 283-306. 
Rajagopalan, N. \& Zhang, Y. 2008. Corporate governance reforms in China and India: Challenges and opportunities. Business Horizons, 51: 55-64.

Rajan, R. G. 1992. Insiders and outsiders: The choice between informed and arm's length debt. Journal of Finance, 47: 1367-1400.

Ravina, E., \& Sapienza, P. 2009. What do independent directors know? Evidence from their trading, Published by Oxford University Press on behalf of The Society for Financial Studies. Advance Access publication April 13, 2009, 962-1003.

Rediker, K.J., \& Seth, A. 1995. Boards of directors and substitution effects of alternative governance mechanisms. Strategic Management Journal, 16: 85-99.

Samuel, C. 1996. Stock market and investment: Governance role of the market. Policy Research Working Paper No. 1578, The World Bank, Washington DC.

Scott, R. A. 1976. Deviance, sanctions, and social integration in small scale societies. Social Forces, 54: 604-620.

Shleifer, A., \& Vishny, R.W. 1986. Large shareholders and corporate control. Journal of Political Economy, 94(3): 461-488.

Shleifer, A., \& Vishny, R.W. 1994. Politicians and firms, Quarterly Journal of Economics, 109(4): 995-1025.

Shleifer, A., \& Vishny, R. W. 1997. A Survey of Corporate Governance, Journal of Finance, American Finance Association, 52(2): 737-83, June.

Shleifer, A., \& Vishny, R.W. 1998, The grabbing hand: Government pathologies and their cures, Cambridge, MA: Harvard University Press.

Singh, A. 2003. Corporate governance, corporate finance and stock markets in emerging countries. Working Paper No. 258, ESRC Centre for Business Research, University of Cambridge, UK.

Sitkin, S. B., \& Roth, N. L. 1993. Explaining the limited effectiveness of legalistic remedies for trust/distrust. Organization Science, 4: 367-392.

Sundaramurthy, C., \& Lewis, M. 2003. Control and collaboration: Paradoxes of governance. Academy of Management Review, 28: 397-415.

Tang, X. 2008, Protecting minority shareholders in China: A task for both legislation and enforcement. In Curtis Milhaupt (ed.) A Decade after Crisis: Transforming Corporate Governance in East Asia, London: Taylor \& Francis Books (2008). 
Thomsen, S., \& Pedersen T. 2000. Ownership structure and economic performance in the largest European companies. Strategic Management Journal, 21(6): 689-705.

Useem, M. 1996. Investor capitalism: How money managers are changing the face of corporate America. $1^{\text {st }}$ edition. Basic Books (New York).

Vickers, J., \& Yarrow, G. 1989. Privatisation, MIT Press.

Von Thadden, E.L. 1995. Long-term contracts, short-term investment and monitoring. Review of Economic Studies, 62: 557-575.

Ward, A.J., Brown, J.A., \& Rodriguez, D. 2009. Governance bundles, firm performance, and the substitutability and complementarity of governance mechanisms. Corporate Governance: An International Review, 17: 646-660.

Wealth Magazine (Tsai Tsun). 2002. Tycoons making friends with the KMT and DPP (in Chinese). August.

Weimer, J. \& Pape, J.C. 1999. A taxonomy of systems of corporate governance. Corporate Governance: an International Review, 7: 152-166.

Westphal, J. D. \& Zajac, E. 1997. Defections from the inner circle: Social exchange, reciprocity, and the diffusion of board independence in U.S. corporations. Administrative Science Quarterly, 42: $161-83$.

Westphal, J. D. 1999. Collaboration in the boardroom: Behavioral performance consequences of CEO-board social ties. Academy of Management Journal, 42: 7-24.

Westphal, J. D., \& Khanna, P. 2003. Keeping directors in line: Social distancing as a control mechanism in the corporate elite. Administrative Science Quarterly, 48: 361-398.

Westphal, J. D., \& Stern, I. 2006. The other pathway to the boardroom: How interpersonal influence behavior can substitute for elite credentials and demographic majority status in gaining access to board appointments. Administrative Science Quarterly, 51: 169-204.

Westphal, J.D. \& Stern, I. 2007. Flattery will get you everywhere (especially if you are a male causasian): How ingratiation, boardroom behavior, and demographic minority status affect additional board appointments at U.S. companies. Academy of Management Journal, 50: 267-288.

Westphal, J.D. \& Zajac, E.J. 2013. A behavioral theory of corporate governance: Explicating the mechanisms of socially situated and socially constituted agency. Academy of Management Annals, 7: 605-659.

Wood, A. L. 1974. Deviant behavior and control strategies. Lexington, MA: Lexington Books. 
Xin, K.R., \& Pearce, J.L. 1996. Guanxi: Connections as substitutes for formal institutional support. Academy of Management Journal, 39: 1641-1658.

Yermack, D. 2004. Remuneration, retention, and reputation incentives for outside directors, Journal of Finance, 59, 2281-2308.

Yoshikawa, T., \& Rasheed, A. 2009 Convergence of corporate governance: Critical review and future directions. Corporate Governance: An International Review, 17: 388-404.

Zhang, R.L. 2012. Report on the HKIoD Corporate Governance Score-card 2012. Hong Kong Institute of Directors. 
Table 1: Outside Directors' Engagement in Managerial Monitoring and Resource Provision in Different Corporate Governance Systems

\section{Types of Corporate Ownership Structure}

\begin{tabular}{|c|c|c|c|c|}
\hline & & Dispersed Ownership & $\begin{array}{c}\text { Concentrated Ownership of } \\
\text { Family }\end{array}$ & $\begin{array}{c}\text { Concentrated Ownership } \\
\text { of the State }\end{array}$ \\
\hline & $\begin{array}{c}\text { Under-developed } \\
\text { National Governance } \\
\text { System }\end{array}$ & 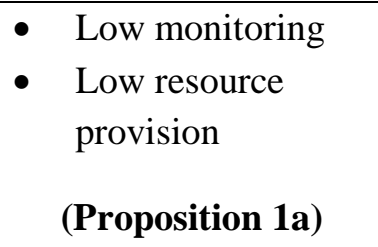 & $\begin{array}{l}- \text { Low monitoring } \\
\text { - } \text { High resource } \\
\text { provision } \\
\text { (Proposition 2a) }\end{array}$ & 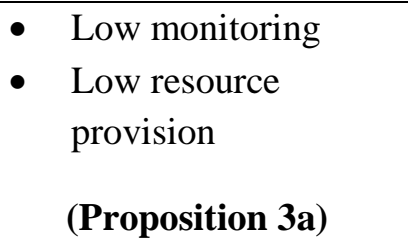 \\
\hline Systems & $\begin{array}{c}\text { Well-developed } \\
\text { National Governance } \\
\text { System }\end{array}$ & $\begin{array}{l}\text { - High monitoring } \\
\text { - High resource } \\
\text { provision } \\
\text { (Proposition 1b) }\end{array}$ & 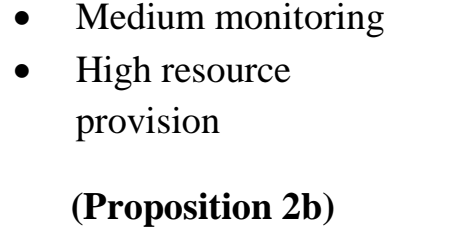 & $\begin{array}{ll}- & \text { High monitoring } \\
\text { - } & \text { Medium resource } \\
\text { provision } \\
\\
\text { (Proposition 3b) }\end{array}$ \\
\hline
\end{tabular}

